Animal Health Research Institute,

Alexandria Branch

\title{
PREVALENCE OF PSYCHROTROPHIC FOOD BORNE PATHOGENS IN FISH IN ALEXANDRIA MARKETS
}

(With 4 Tables)

By

AMAL.F.A. MANSOUR and F.A. EL-SHABOURY

(Received at 16/3/2009)

مدي تواجد الميكروبات الممرضة المحبة للبرودة في الأسماك في أسواق محافظة الإسكندرية المحنة المرو

آمال فههي علي منصور ، فتح الله علي الشابوري

تم جمع 100 عينة من الأسماك الطازجة عبارة عن 50 عينة من أسماك البلطي و 50 عينة

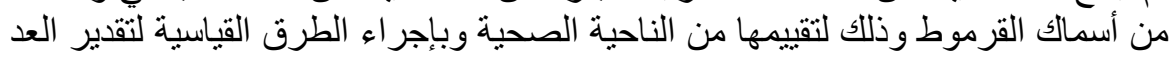

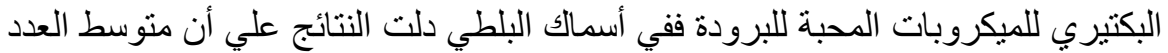

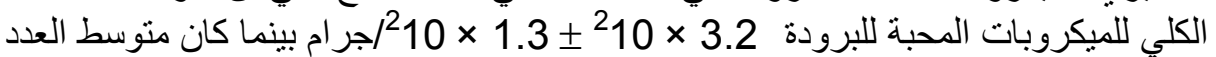

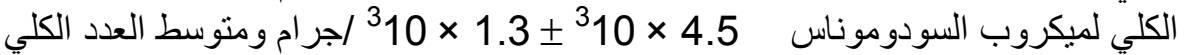

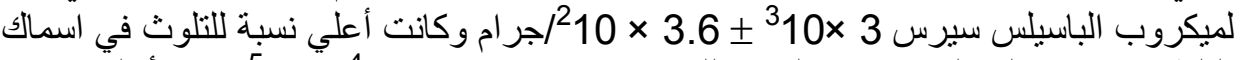

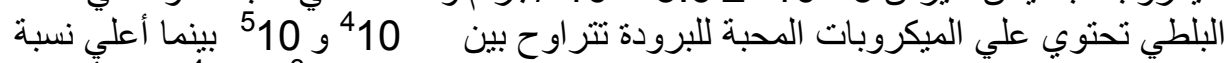

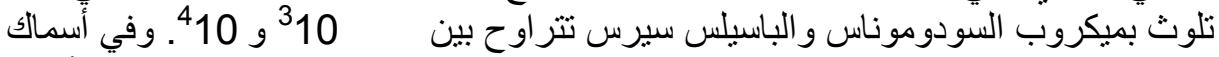

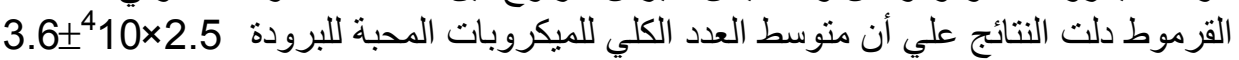

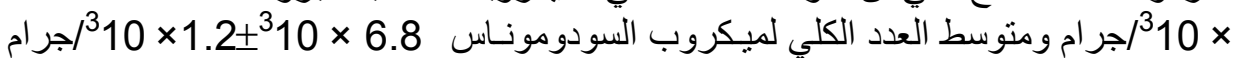
و ومنوسط العدد الكلي لميكروب الباسيلس سيرس

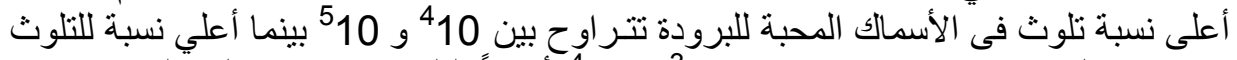

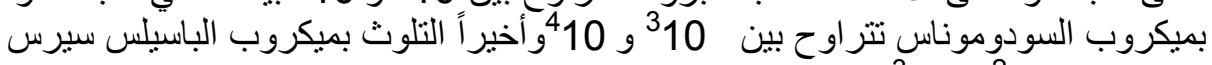

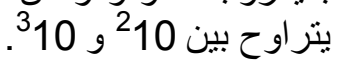

\section{SUMMARY}

One hundred samples of fish represented by 50 samples of Tilapia nilotica and 50 samples of Claris lazera were collected from different fish markets in Alexandria Governorate to evaluate their microbiological quality and detection of food borne psychrotrophs. The bacteriological examination revealed that the mean values of total psychrotrophic count, total Pseudomonas count and total Bacillus cereus count in Tilapia nilotica were $3.2 \times 10^{2} \pm 1.3 \times 10^{2}, 4.5 \times 10^{3} \pm 1.3 \times 10^{3}$ and $3 \times 10^{3} \pm$ 
$3.6 \times 10^{2}$ respectively. The majority of Tilapia nilotica fish samples had psychrotrophic count ranged from $10^{4}$ to $<10^{5}$. While, the majority of such examined fish samples had Pseudomonas and Bacillus cereus count between $10^{3}$ to $10^{4}$. Furthermore, the avarage counts of psychrotrophics, Pseudomonas and Bacillus cereus for Claris lazera were $2.5 \times 10^{4} \pm 3.6 \times 10^{3}, 6.8 \times 10^{3} \pm 1.2 \times 10^{3}$ and $8.6 \times 10^{2} \pm 2.1 \times 10^{2}$ respectively. The public health significance of the isolated microorganisms and possible sources of contamination of fish with such organisms as well as some recommendations to improve the quality of fish were discussed.

Key words: Fish, Tilapia nilotica, Claris lazera, psychrotrophs, B-cereus, Pseudomonas spp.

\section{INTRODUCTION}

Fish and fish products were incriminated as causes of food poisoning, food intoxication, allergic and skin disorders as well as other many infectious diseases (Lawsan, 1970). Microorganisms, individually and as a group, grow over a very wide range of temperatures. Therefore, it would be well to consider at this point the temperature growth ranges for organisms of importance in foods as an aid in selecting the proper temperature for the storage of different types of foods.

Psychrotrophs are those organisms that grow well at or below $7^{\circ} \mathrm{C}$ and have their optimum between $20^{\circ} \mathrm{C}$ and $30^{\circ} \mathrm{C}$. Bacillus cereus and species of Pseudomonas were found among the psychrotrophic microorganisms, and their presence or contamination of food creates a great risk as they lead to food poisoning and/or spoilage of food products (Jay, 2000). In addition (Parry et al., 1983) mentioned that Bacillus cereus causes health hazard to consumers, and also important for economic as they cause spoilage and deterioration of meat and meat products and responsible for food poisoning outbreaks among the consumers. Refrigeration is often the main and frequently the only factor to control food-borne pathogens in these types of foods. Hence, temperature abuse of such foods can result in food-borne illness. In addition, some psychrotrophic pathogens can grow in refrigerated foods with little or no obvious change of sensory characteristics (Berrang et al., 1989). Bacillus cereus can give rise to two distinct forms of food-borne disease, the emetic forms and the diarrhaeal syndromes. The emetic form belived to be associated with an emetic toxin performed in food while the diarrhaeal type is caused by an enterotoxin (Altayer and Sutherland, 2006). 
Pseudomonas species were responsible for spoilage and the identified off-odours, odours produced by the spoilage Pseudomonas bacteria were varied that resemble sulpher, amonia and bad odour (Russel et al., 1995) Pseudomonas microorganisms were isolated and determined as causes for contamination and spoilage of fishes (Gram and Melchiorsen, 1996; Yumoto et al. 1999; Carraseal et al. 2002). The wide spread occurrence and psychrotrophic nature of these bacteria could increase the risk as refrigerated ready-to-eat foods may serve as vehicles of food-borne illness. The aim of this study was to assess the presence of some psychrotrophic microorganisms in ready-to-eat fishes. The health risks due to these pathogens for consumers were also discussed.

\section{MATERIALS and METHODS}

\section{Collection of samples:}

A total of 100 random ready-to-eat fish samples, 50 each of Tilapia nilotica and Claris lazira were collected from fish markets in Alexandria city. The collected samples were transferred in an ice box immediately to the laboratory under complete aseptic precaution without undue delay for bacteriological examination.

\section{Preparation of samples (APHA, 1984)}

10 grams of each of fish and $90 \mathrm{ml}$ of sterile peptone water were added and thoroughly mixed by using sterile blender for approximately 2.5 minutes, from which ten fold serial dilutions were prepared. The prepared samples were subjected to the following examination.

\section{1- Determination of psychrotrophic bacterial count:}

Standard plate count agar was used as recommended by APHA (1992). The average number of colonies per gram was determined and the psychrotrophic count/g samples was calculated and recorded.

\section{2- Enumeration and identification of Pseudomonas species (ICMSF, 1978):}

$0.1 \mathrm{ml}$. of each fish muscle dilutions was separately inoculated into duplicated Petri-dishes of Pseudomonas selective agar medium supplemented with glycerol. The inoculated plates were incubated at $25^{\circ} \mathrm{C}$ for 48 hours after which all developed colonies (greenish yellow pigment) were enumerated and the avarage count/g was calculated and recorded.

\section{3-Enumeration and identification of Bacillus cereus (ISO, 1987):}


The spreading technique was applied on the surface of Bacillus cereus selective agar which incubated at $37^{\circ} \mathrm{C}$ for 24 hours, then the count was recorded. Colonies though to be Bacillus cereus were identified by microscopical examination and biochemical reactions.

\section{RESULTS}

Table 1: Statistical analysis of total psychrotrophic, Pseudomonas and Bacillus cereus of the examined Tilapia nilotica $(n=50)$.

\begin{tabular}{|l|c|c|c|}
\hline Bacterial count & $\begin{array}{c}\text { Total } \\
\text { Psychrotrophic }\end{array}$ & Pseudomonas & Bacillus cereus \\
\hline Minimum & $1.7 \times 10^{3}$ & $7 \times 10^{2}$ & $7.8 \times 10^{2}$ \\
\hline Maximum & $3 \times 10^{4}$ & $2.6 \times 10^{4}$ & $8 \times 10^{3}$ \\
\hline Mean & $3.2 \times 10^{2}$ & $4.5 \times 10^{3}$ & $3 \times 10^{3}$ \\
\hline Standard error & $1.3 \times 10^{2}$ & $1.3 \times 10^{3}$ & $3.6 \times 10^{2}$ \\
\hline
\end{tabular}

Table 2: Frequency distribution of the examined Tilapia nilotica based on their total psychrotrophic, Pseudomonas and Bacillus cereus counts $(n=50)$.

\begin{tabular}{|l|c|c|c|c|c|c|}
\hline \multirow{2}{*}{ Range } & \multicolumn{2}{|c|}{ Total Psychrotrophic } & \multicolumn{2}{c|}{ Pseudomonas } & \multicolumn{2}{c|}{ Bacillus cereus } \\
\cline { 2 - 7 } & No. & $\%$ & No. & $\%$ & No. & $\%$ \\
\hline$<10^{2}$ & 25 & 50 & 27 & 54 & 28 & 56 \\
\hline $10^{2}<10^{3}$ & 0 & 0 & 3 & 6 & 4 & 8 \\
\hline $10^{3}<10^{4}$ & 10 & 20 & 12 & 24 & 18 & 36 \\
\hline $10^{4}<10^{5}$ & 15 & 30 & 8 & 16 & 0 & 0 \\
\hline
\end{tabular}

$<10^{2}$ mean negative result.

Table 3: Statistical analysis of total psychrotrophic, Pseudomonas and Bacillus cereus count of Claris lazera $(n=50)$.

\begin{tabular}{|l|c|c|c|}
\hline \multicolumn{1}{|c|}{ Bacterial count } & Total psychrotrophic & Pseudomonas & Bacillus cereus \\
\hline Minimum & $2.0 \times 10^{3}$ & $4.0 \times 10^{2}$ & $<10^{2}$ \\
\hline Maximum & $6.1 \times 10^{4}$ & $2.0 \times 10^{4}$ & $3.0 \times 10^{3}$ \\
\hline Mean & $2.5 \times 10^{4}$ & $6.8 \times 10^{3}$ & $8.6 \times 10^{2}$ \\
\hline Standard error & $3.6 \times 10^{3}$ & $1.2 \times 10^{3}$ & $2.1 \times 10^{2}$ \\
\hline
\end{tabular}


Table 4: Frequency distribution of the examined Claris lazera based on their total psychrotrophic, Pseudomonas and Bacillus cereus counts $(n=50)$.

\begin{tabular}{|c|c|c|c|c|c|c|}
\hline Count & \multicolumn{2}{|c|}{ Total psychrotrophic } & \multicolumn{2}{|c|}{ Pseudomonas } & \multicolumn{2}{|c|}{ Bacillus cereus } \\
\hline Rang & No. & $\%$ & No. & $\%$ & No. & $\%$ \\
\hline$<10^{2}$ & 25 & 50 & 32 & 64 & 33 & 66 \\
\hline $10^{2}<10^{3}$ & 0 & 0 & 0 & 0 & 10 & 20 \\
\hline $10^{3}<10^{4}$ & 7 & 14 & 14 & 28 & 7 & 14 \\
\hline $10^{4}<10^{5}$ & 18 & 36 & 4 & 8 & 0 & 0 \\
\hline
\end{tabular}

$<10^{2}$ mean negative result.

\section{DISCUSSION}

The psychrotrophic bacteria have been received an increased attention by several investigators during recent years because the modern developments in fish production which resulted in that fish must be held for longer period at low temperature before transportation, processing manufacture or consumption.

Regarding the results recorded in Table (1) it is obvious that the total psychrotrophic count of the examined Tilapia nilotica samples had a count ranged from $1.7 \times 10^{3}$ to $3 \times 10^{4}$ with a mean value of $3.2 \times 10^{2} \pm$ $1.3 \times 10^{2}$, while the total Pseudomonas count ranged from $7 \times 10^{2}$ to $2.6 \times 10^{4}$ with a mean value of $4.5 \times 10^{3} \pm 1.3 \times 10^{3}$. Finally, the Bacillus cereus count had minimum, maximum and a mean values of $7.8 \times 10^{2}$, $8 \times 10^{3}$ and $3 \times 10^{3} \pm 3.6 \times 10^{2}$ respectively.

Variable figures were reported by Hassan (1991) who recorded that the log. mean value was 7.8 \pm 7.2. Mousa and Mahmoud (1991) recorded that the mean values of the total psychrotrophic counts of examined Tilapia nilotica was $0.56 \times 10^{2} \pm 0.028 \times 10^{2} / \mathrm{g}$. While Mahmoud (1994) recorded that the log. mean values of the total psychrotrophic count in the examined Tilapia nilotica was 5.84 \pm 0.090 . Higher counts were recorded by Hobbs (1983), Jay (1986) and Hayes (1992). The presence of psychrotrophic organisms in fish may be attributed to contamination from environment around the fish. The processing, equipments, workers, containers, boxes, as well as using polluted water during transportation play an important role for increase counts of psychrotrophic bacteria. Also delaying refrigeration after harvesting and 
other handling errors between harvesting and processing lead to decomposition of the fish and allow microbes to grow rapidly (Marriott, 1997).

Pseudomonas species was isolated from fresh water fish by Gram (1993), Mousa and Mahmoud (1997) and Walaa Omer (2004). Lower Pseudomonas counts in the examined Tilapia nilotica samples was recorded by Lamada-Hanan (1999) with a mean value of $5.4 \times 10^{2}$ $\pm 1.1 \times 10^{2}$. Pseudomonas species are widely distributed in nature, polluted water, unsanitized equipments, fishermen hands during harvesting, transportation and storage are the source of fish contamination (Venugopal, 1990).

Bacillus cereus was widely distributed in nature, water, soil, air and dust and can be isolated from a wide variety of foods which it may be normally present. The frequency distribution of the total psychrotrophic count of Tilapia nilotica was recorded in table (2) and revealed that the majority of samples lied between $10^{4}$ to $10^{5}$, while the majority of such examined samples had Pseudomonas and Bacillus cereus count between $10^{3}$ to $10^{4}$.

Regarding Claris lazera fish samples examined, the result reported in Table (3) revealed that psychrotrophic count ranged from $2 \times 10^{3}$ to $6.1 \times 10^{4}$ with a mean value $2.5 \times 10^{4} \pm 3.6 \times 10^{3} / \mathrm{g}$. While the total Pseudomonas count ranged from $4 \times 10^{2}$ to $2 \times 10^{4}$ with a mean value $6.8 \times 10^{3} \pm 1.2 \times 10^{3} / \mathrm{g}$, and finally, the Bacillus cereus count ranged from $<10^{2}$ to $3 \times 10^{3}$ with a mean value of $8.6 \times 10^{2} \pm 2.1 \times 10^{2} / \mathrm{g}$.

Mousa and Mahmoud (1997) found a lower psychrotrophic count in the examined Claris lazera fish samples where the mean value was $0.78 \pm 0.022 \times 10^{3}$.

Table (4) indicated that the frequency distribution of the total psychrotrophic count of the examined Claris lazera had a majority count lied between $10^{4}$ to $<10^{5}$, while Pseudomonas and Bacillus cereus counts lied between $10^{3}$ to $<10^{4}$ and $10^{2}$ to $<10^{3}$ respectively.

Growth of psychrotrophic bacteria in fish has become a significant problem due to the wide spread use of refrigerated storage of fish, and finally we must know that psychrotrophic bacteria when grow in fish can induce different varities of off-flavour including fruity, putrid, ranced flavour as well as other physical defects. 


\section{REFERENCES}

Altayar, M. and Sutherland, A.D. (2006): Bacillus cereus is a common in the environment but emetic toxin producing isolates are rare. $\mathrm{J}$. Appl. Microbiology, 100(1): 7-14.

APHA "American Public Health Association" (1984): Compendium of Methods for Microbiological Examination of Foods. $2^{\text {nd }}$. Edition. Washington, D.C.

APHA "American Public Health Association" (1992): Compendium of Methods for Microbiological Examination of Foods. $3^{\text {rd }}$ Ed. Washington, D.C.

Berrang, M.E.; Brachett, R.E. and Beuchat, L.R. (1989): Growth of Listeria monocytogenes on fresh vegetables stored under a controlled atmosphere. J. Food Prot. (52): 702-705.

Carraseal, A.; Arrienta, G. and Mattar, S. (2002): Preliminary study of microbiological quality of foods on the Colombian Atlantic Coast. Informe Quincenal-Epidemiologico Nacional, 7(11): 163-169.

Gram, L. and Melchiorsen, J. (1996): Interaction between fish spoilage bacteria Pseudomonas spp. and shewanella putrefaciens in fish extracts and on fish tissue. J. Appl. Bacteriol. 80(6): 589.

Hassan, M.T. (1991): Microbiological status of frozen dressed fish. M.V.Sc.

Thesis Fac. Vet. Med., Moshtohor, Zagazig University-Benha.

Hayes. P.R. (1992): Food Microbiology and Hygiene. $2^{\text {nd }}$ ed. El-Sevier Science Publishers (L.Td).

Hobbs, G. (1983): Microbial spoilage of fish. In food advances and prospects report. T.A. and Skinner, F.A. (Eds), Society for App. Bact. Symposium series. No. 11, Academic Press London, 217-229.

ICMSF "International Commission on Microbiological Specification for foods" (1978): Microorganisms in Foods, Their Significance and Methods of Enumeration. $2^{\text {nd }}$ Ed. Univ. of Toronto Press. Toronto, Buffalo. Canada.

ISO (1987): Microbiology-General guidance for enumeration of Bacillus cereus. ISO 7932. Geneva, Switzerland.

Jay, M.J. (1986): Modern Food Microbiology. $3^{\text {rd }}$ ed. CBS Publisher and distributers. Indian-Edition.

Jay, M.J. (2000): Modern Food Microbiology. Sixth Ed. Gaithersburg. Maryland. 
Lamada-Hana, M.O. (1999): Chemical and sensory changes associated with microbial flora of Mediterranean boque (Boops boops) stored aerobically at $0,3,7$ and $10^{\circ} \mathrm{C}$. Appl. Environ, Microbiol. 65(2): 698.

Lawsan, T.B. (1970): Some aspects of fish inspection and public health. Vet. Reas., 87: 528.

Mahmoud, Y.E. (1994): Studies on frozen fish ph.D. Thesis. Fac. Vet. Med., Moshtohor. Zagazig University. Benha.

Marriott, N.G. (1997): Essential of food sanitation. Consulting Editor, Gill Robertson Chapman and hall $1155^{\text {th }}$ avenue, New York.

Mousa, M.M. and Mahmoud, Y.E. (1997): Hygienic quality of newly caught fresh fish. Assiut. Vet. Med. J. 73: 219-233.

Omer, I.A. Walla (2004): Antibiotic resistance of Pseudomonas species isolated from fish and farm animals. Ph.D. Thesis. Fac. vet. Med. Alexandria.

Parry, J.M.; Turnbull, P.C.B. and Gibson, J.R. (1983): A colour Atlas of Bacillus species. Wolf Medical Publication Ltd. London.

Russell, S.M.; Fletcher, D.L. and Cox, N.A. (1995): Spoilage bacteria of fresh broiler chicken carcasses. Poultry Sci., 74: 2041-2047.

Venugopal, V. (1990): Extracellular proteases of contaminant bacteria in fish spoilage. J. Food Prot., 53: 341-350.

Yumoto, I.; Iwata, H.; Sawabe, T.; Meno, K.; Ichise, N.; Matsuyama, H.; Okuyama, H. and Kawasaki, K. (1999): Characterization of facultatively Psychrophillic bacterium, vibrio rumoiensis sp. Nov., that exhibits high catalase activity. Appl. Environ. Microbiol. 65(1): 67-72. 